\title{
ХРОНИКА
}

DOI: 10.17805/trudy.2016.6.11

\section{IV МЕЖДУНАРОДНАЯ НАУЧНО-ПРАКТИЧЕСКАЯ КОНФЕРЕНЦИЯ «ЦЕННОСТИ И ИНТЕРЕСЫ СОВРЕМЕННОГО ОБЩЕСТВА»"}

\author{
О. Э. Башина \\ (Московский гуманитарный университет)
}

Аннотация: В статье представлен обзор работы IV Международной научно-практической конференции «Ценности и интересы современного общества», которая прошла 17-21 октября 2016 г. в Московском гуманитарном университете.

Ключевые слова: конференция; обзор; ценности; современное общество; интересы; Московский гуманитарный университет

\section{$4^{\text {TH }}$ INTERNATIONAL CONFERENCE "VALUES AND INTERESTS OF CONTEMPORARY SOCIETY”}

\author{
O. E. Bashina \\ (Moscow University for the Humanities)
}

Abstract: This is an overview of the 4th international research conference "Values and Interests of contemporary society" which was held on October 17-21 at Moscow University for the Humanities.

Keywords: conference; overview; values; contemporary society; interests; Moscow University for the Humanities

С 17 по 21 октября 2016 г., в Московском гуманитарном университете при поддержке Российского гуманитарного научного фонда была проведена IV Международная научно-практическая конференция «Ценности и интересы современного общества».

Цель конференции - обсуждение актуальных теоретических и практических вопросов развития социально-экономической сферы, включая

\footnotetext{
" Подготовлено при финансовой поддержке РГНФ (грант №16-02 14050«г»), а также в рамках проекта проведения научных исследований «Разработка подходов к созданию системы оценки состояния и определения перспективных направлений развития научной сферы» (грант № 16-02-00407«а»).

The article was prepared with financial support from the Russian Foundation for the Humanities (Grant No. 16-02 14050 r, "Approaching the system of assessing the current state and promising directions for the sphere of science").
} 
ее правовые, политические, социально-культурные и экономические аспекты. Общее количество участников конференции составило 820 человек, в их числе представители Государственной Думы РФ, государственных и региональных органов управления, руководители корпораций, бизнес-сообществ, омбудсмены, представители различных фондов. Основной количественный состав участников - представители учебных заведений высшего образования, научных сообществ Российской Федерации, стран ближнего и дальнего зарубежья. В частности, в работе конференции приняли участие 220 аспирантов, магистрантов и студентов МосГУ и других российских вузов.

В рамках работы конференции состоялось 11 секций и круглых столов. На них были рассмотрены актуальные вопросы современности: ценности российской цивилизации и общество потребления; роль ценности национальной идентичности в эпоху глобализации; модернизация политических систем государств в условиях ценностных трансформаций; духовные основания жизни русской деревни; современные направления молодежной музыкальной культуры: соотношение свободы и нравственности; проблемы информационного неравенства молодежи в контексте новых технологий; ценностные ориентации российской и китайской молодежи (сравнительный анализ); смысл жизни как высшая ценностная ориентация; ценности свободы и демократии в политической культуре российского общества; проблема истинных и ложных ценностей в работе Э. Фромма «бегство от свободы» и отношение к ней в современной России; особенности формирования политических ценностей; нравственнодуховные начала в систематизации законодательства о праве собственности; нормы морали в процессе назначения уголовных наказаний.

Рассматривались вопросы формирования духовно-нравственного портрета современного студента, парадоксов и ценностей современного воспитания; раскрыт ценностный статус детства в современном обществе и роль учителя в формировании личности учащегося. Затронуты проблемы психолого-педагогического сопровождения студентов с нарушением интеллекта. В рамках исторического аспекта рассмотрена роль России в формировании Победы во время Великой отечественной войны и историческая память о том драматическом времени. Значительное внимание участники конференции уделили: развитию образования как фактору модернизации российской экономики; современным IT-технологиям в образовательном процессе; профессиональному образованию и подготовке кадров для современной экономики; нравственному воспитанию молодежи; развитию научного потенциала в России.

Таким образом, развитие модернизационных процессов российской экономики рассматривались в контексте стратегического развития цен- 
ностей и интересов современного общества.

Перспективные направления и актуальные задачи развития социально-экономических ценностей в интересах современного общества и итоги работы конференции были обсуждены на пленарном заседании в последний день работы - 21 ноября 2016 г.

Открыла пленарное заседание проректор по научной работе МосГУ, доктор педагогических наук Л. В. Романюк, которая от имени ректората университета приветствовала гостей и участников конференции, пожелала им плодотворной научной дискуссии и поручила дальнейшее ведение пленарного заседания д. ю. н., профессору С. Н. Бабурину, президенту Славянской академии наук, образования, искусств и культуры, президенту Ассоциации юридических вузов, главному научному сотруднику Института социально-политических исследований РАН, Заслуженному деятелю науки РФ.

Заместитель директора Центра исследований в сфере экономики и права (ЦИСЭП), к. э. н. Л. В. Шур-Труханович в докладе «Нарастающие тренды изменения содержания правотворческой работы» остановилась на возможном опережающем и активном регулировании правотворческой работы.

Заместитель директора Департамента экономического сотрудничества со странами СНГ и развития евразийской интеграции Минэкономразвития РФ, д. э. н. П. А. Шевцов исследовал вызовы устойчивому развитию СНГ в условиях современной реальности.

Директор Научно-исследовательского института проблем социальноэкономической статистики (НИИ статистики Росстата), к. э. н. О. П. Рыбак выполнил анализ основных тенденций инвестиционной активности в России.

Особое внимание участников пленарного заседания привлекло выступление Начальника Управления содействия международному развитию и взаимодействию с международными организациями Россотрудничества Л. Г. Макурова.

Президент компании «АЛРОСА», к. э. н. А. В. Жарков дал информацию о состоянии и перспективах развития компании и ее влиянию на социально-экономическое развитие Республика Саха (Якутия).

Руководитель Юридического дивизиона «МЕТРО Кэш енд Керри» Д.Д.Хрущалев остановился на современных проблемах регулирования торговой деятельности.

В пленарном заседании приняли участие представители стран ближнего и дальнего зарубежья: заведующий кафедрой конституционного права Белорусского государственного университета, д. ю. н., профессор А. И. Забейворота (Республика Беларусь) с докладом «Организация и дея- 
тельность Евразийского экономического союза»; заведующий кафедрой истории Казахстана и общественных наук Казахского университета международных отношений и мировых языков им. Абылай хана, д. ф. н., профессор 3. С. Айдарбеков (Республика Казахстан) с докладом «Ценности эффективного управления в усложненном мире»; директор-учредитель «Baltic Centre for professional training and development» И. Ю. Трояновская (Латвийская Республика) в докладе «Развитие электронного образования в Латвии»; исполнительный директор некоммерческой организации «Фонд развития трудовых ресурсов концерна «РОСЭНЕРГОАТОМ» Б. В. Кобахия (Республика Абхазия) дал подробный анализ социальноэкономического и политического положения Абхазии в современном мире.

От регионов Российской Федерации выступили: генеральный директор ООО «Авангард», обеспечивающего хлебобулочными изделиями Владимирскую, Калужскую, Липецкую и др. области Центрального Федерального округа России, к. э. н. Н. Н. Калинин; начальник отдела реализации семейной политики Министерства труда и социальной защиты Калужской области Е. А. Буслаева; проректор по воспитательной работе и молодежной политике Тульского государственного педагогического университета им. Л. Н. Толстого, руководитель Межрегионального центра развития кадрового потенциала молодежной политики по Центральному Федеральному округу, д. п. н., профессор 3. Н. Калинина.

В рамках пленарного заседания с докладами выступили представители партнерских научных и образовательных организаций: главный научный сотрудник Института проблем информатики Федерального исследовательского центра «Информатика и управление» РАН, д. т. н., профессор К. К. Колин с докладом «Новая методология измерения качества жизни в современном обществе»; заместитель заведующего кафедрой истории зарубежных стран МГУ им. М. В. Ломоносова, д. э. н., профессор Л. Н. Доброхотов - «История Российско-Американских отношений до выборов в США и прогнозы развития дальнейших отношений после выборов»; советник по экономическим вопросам Национального института бизнеса, д. э. н., профессор Н. Л. Пирогов - «Роль инноваций для экономического развития страны»; доцент кафедры этики МГУ им. М. В. Ломоносова, к. ф. н. Т. И. Пороховская в выступлении оценила текущее состояние общества как современный ценностно-мировоззренческий кризис и рассмотрела пути его решения.

Результаты конференции будут опубликованы в научных журналах

Московского гуманитарного университета и изданном в двух томах сборнике научных трудов конференции, включающем 140 статей общим объемом издания $-43,7$ п. л. (Ценности и интересы ..., 2016ab).

По итогам работы секций, круглых столов и пленарного заседания вы- 
работаны и направлены в адрес Государственной Думы РФ, Минкультуры России, Минпромторга России, Минэкономразвития России предложения по совершенствованию законодательства РФ в социально-экономической сфере, а в адрес Минобрнауки России - представления по совершенствованию научной и образовательной деятельности.

\section{СПИСОК ЛИТЕРАТУРЫ}

Ценности и интересы современного общества (2016a): материалы IV Международной научно-практической конференции: в 2-х т. М. : Издательство Московского гуманитарного университета. Т. 1. 343 с.

Ценности и интересы современного общества (2016b): материалы IV Международной научно-практической конференции: в 2-х т. М. : Издательство Московского гуманитарного университета. Т. 2. 272 с.

Дата поступления: 11.12.2016 2.

Башина Ольга Эмильевна - доктор экономических наук, профессор, заведующая кафедрой статистики, маркетинга и бухгалтерского учета Московского гуманитарного университета; заслуженный деятель образования Российской Федерации. Адрес: 111395, Россия, г. Москва, ул. Юности, д. 5. Тел.: +7 (499) 374-58-60. Эл. адрес: obashina@mosgu.ru

Bashina Ol'ga Emil'yevna, Doctor of Economics, Professor and Chair, Department of Statistics, Marketing and Accounting, Moscow University for the Humanities, Honored Worker of Education of the Russian Federation. Postal address: 5 Yunosti St., 111395 Moscow, Russian Federation. Tel.: +7 (499) 37458-60.E-mail: obashina@mosgu.ru

\section{Для циттрования:}

Башина О. Э. IV Международная научно-практическая конференция «Ценности и интересы современного общества» [Электронный ресурс]// Научные труды Московского гуманитарного университета. 2016, № 6. URL: http://journals.mosgu.ru/trudy/ article/view/382 (дата обращения: дд.мм.гг.). 